\title{
Is There an East-West Divide over European Solidarity? Comparing European Citizens' Attitudes Towards Cross-Border Solidarity 2016
}

\author{
Florian K. Kley and Holger Lengfeld
}

\section{INTRODUCTION $^{1}$}

Media and academic debates concerning the Visegrád governments rejecting the EU refugee relocation scheme and their criticism of 'Brussels' suggest that the East Central European countries are marked

${ }^{1}$ This research was part of a joint venture between the international research project Solidarity in Europe: Empowerment, Social Justice and Citizenship-SOLIDUS funded by the European Commission through the Horizon 2020 research programme (Grant Agreement n. 649489) and the research unit Horizontal Europeanisation funded by the Deutsche Forschungsgemeinschaft (DFG) (FOR 1539). This chapter is based on an unpublished final survey report provided to the European Commission (Gerhards et al. 2017).

F. K. Kley $(\bowtie) \cdot$ H. Lengfeld

Institute of Sociology, Leipzig University, Leipzig, Germany

e-mail: florian.kley@uni-leipzig.de

H. Lengfeld

e-mail: holger.lengfeld@uni-leipzig.de

(C) The Author(s) 2021

A. Lorenz and L. H. Anders (eds.), Illiberal Trends and Anti-EU Politics

in East Central Europe, Palgrave Studies in European Union Politics, https://doi.org/10.1007/978-3-030-54674-8_4 
by strong anti-EU politics and attitudes. To contextualise this impression, this chapter analyses European solidarity in different fields of European integration. In recent years, a series of crises have hit the European Union (EU) with the refugee crisis being only one of them. These crises have challenged solidarity between both European citizens and member states of the EU. In this chapter, we investigate attitudes towards different domains of transnational solidarity of citizens from East Central European (ECE) and other European countries: firstly, the European banking and financial crisis, and secondly, the Great Recession.

The European banking and financial crisis of 2008 resulted from massive insolvencies in the American real estate market that jeopardised the stability and liquidity of several major European banks. To save banks teetering on the brink of bankruptcy, some EU member states took out large government loans, which resulted in adverse deficits in their national budgets. The mismatch between drastically increased government debts and stagnating gross domestic products led to a devaluation of the (international) credit status of some European countries. Moreover, the sovereign debt crisis weakened the Euro as a whole and put the European Monetary Union (EMU) under pressure. These institutional deficits were tackled by a series of financial support measures provided by the International Monetary Fund (IMF), the European Central Bank (ECB) and not least of all, the EU member states. Although the Maastricht Treaty specifically prohibits such actions (formerly known as the 'No Bailout Clause'), richer countries, followed by EU institutions, de facto allocated financial aid to countries in need. Finally, all these financial measures were publicly subsumed under the well-known term 'bailouts'. We call these emergency financial measures among EU member states European fiscal solidarity.

The following economic crisis (also known as the Great Recession) starting in 2009 was a distinct sort of crisis, which is a direct consequence of the sovereign debt crisis that had besieged some member states. Countries had to meet strict requirements by the EU creditors, who made extensive structural reforms a condition of the bailout measures. While these policy actions are expected to restore economies to sustainable growth in the long term, in some member states the so-called austerity measures even fostered an economic downturn in the short term. In this context, austerity measures have further worsened the situation, especially in the crisis-stricken Mediterranean member states, where the welfare state was comparatively weak even before the crisis (e.g. Gelissen 2000). 
Besides this growing North-South divide come the lasting East-West differences with the economically less powerful countries in Eastern and Central Europe. Thus, we complement our research by adding questions concerning distributional mechanisms between rich and poor countries in Europe. Throughout the chapter, we refer to this as European territorial solidarity.

Regarding public support among citizens from ECE countries, one may assume different results for the two domains of solidarity. ${ }^{2}$ Over the progress of the crises, none of the ECE countries received financial assistance from rescue funds. Public debate and discourses played an important role anyway, when national politicians in Slovakia raised their voice against extensive financial measures for other, wealthier EU member states (Kulish and Castle 2011). Taking into account their comparably low levels of economic wealth, one may assume citizens from the ECE countries could be rather sceptical towards European fiscal solidarity than other member states, especially the crisis-stricken Southern ones. In contrast, one may assume public opinion for European territorial solidarity to be rather pronounced among the peoples of these countries. At the time of their accession in the 2000s, and still today, ECE countries lag behind the economic level of many Central and Western European countries (Eurostat 2017). Having benefitted from the already existing redistribution mechanisms, such as the European Social and Investment Fund, citizens may claim these systems to be extended even further in future to close the intra-European wealth gap. Both solidarity domains were discussed extensively in recent years, making the question of citizens' views on these issues highly relevant.

In this paper, we analyse to what extent citizens from thirteen EU countries are willing to show each form of European solidarity. By doing so, we investigate if and to what extent attitudes of citizens from the three ECE countries of Hungary, Slovakia and Poland differ in comparison with other European countries. In Sect. 2, we will elaborate on the conceptual framework of our study. By European solidarity, we mean a form of solidarity expanded beyond one's own nation state; recipients of solidarity are other EU countries, or citizens living in another EU country. In Sect. 3, we describe the methodology of the data used, the Transnational European Solidarity Survey (TESS). In Sects. 4 and 5, we present

${ }^{2}$ For the concepts of diffuse and specific support of (European) democracy, see Chapter 2. 
descriptive results on the strength of European solidarity. The subjects of the analyses are two domains of European solidarity, territorial and fiscal solidarity, each of which we analyse by referring to a general and more in-depth survey question.

\section{EUROPEAN SOLIDARITY: \\ CONCEPT AND MEASUREMENT}

To ensure an empirically reliable measurement, scholars usually define the term solidarity according to relevant literature. This, however, raises two different issues. On the one hand, scholars researching solidarity face a large amount of different definitions (Bayertz 2000; Hechter 2001). On the other hand, the meaning of the term solidarity is blurred by its day-today use in the political arena, where the term often operates as a normative concept for legitimation (Bayertz and Boshammer 2008).

Against this backdrop, we rely on classical sociological theory and conceive solidarity as a specific form of social action (see Gerhards et al. $2019 \mathrm{~b}$ ). Solidarity is the act of allocating resources which are provided by a donor and given to a recipient in need of the specific resource. This transaction takes place voluntarily without expecting a mutual return. In some cases, solidarity is mediated by a third actor, who pools resources on behalf of the donor(s) and allocates them in a second step. In such a specific case, we speak of institutionalised solidarity. The best-known example of institutionalised solidarity at the national level is the welfare state systems. Because most people do not have an opportunity to directly help fellow Europeans, we base our research on fictive, yet realistic forms of institutionalised solidarity.

Further clarifications of our understanding of 'European solidarity' are important for the empirical measurement. We do not examine real acts of solidarity, but attitudes towards different domains of institutionalised solidarity, i.e. whether citizens are in favour of solidarity. This is theoretically plausible, because according to the 'theory of planned behaviour' (cf. Ajzen 1991), we can assume that the essential preferences of individuals determine their concrete actions. Thus, our operationalisation serves as a reliable proxy for measuring institutionalised solidarity at the European level. Furthermore, we distinguish three dimensions that the construct of solidarity consists of: (1) types of actors, (2) domains and (3) spatial levels. 
1. Regardless of being a donor or recipient, actors are defined as either individuals or collective actors (i.e. regions or nation states). While a European perspective could also focus on solidarity directly towards individual actors in Europe (e.g. supporting the poor in other European countries), we will focus on citizens' attitudes towards institutionalised forms of solidarity where donors and recipients are collective units in the first place.

2. Recipients (both individuals and collective actors) of solidarity may differ in terms of their level of vulnerability in regard to a certain domain of solidarity. A variety of domains or causes of solidarity in Europe can be distinguished. ${ }^{3}$ In our research, we primarily focus on recipients whose circumstances are affected by one of the two crises Europe has recently experienced:

a. Territorial solidarity: This domain takes wealth disparities within a territorial unit into account. Redistribution policies which reduce such inequalities are present within many EU member states, and even between member states in the form of the European Structural and Investment Funds. Hence, we measure territorial solidarity as the support to reduce wealth disparities between poor and rich territorial units.

b. Fiscal solidarity: When collective actors fall into insolvency, betteroff actors act as guarantors. In the case of the financial crisis, better-off member states guaranteed surety for the monetary loans of countries which could not pay back their debt. Therefore, we define fiscal solidarity as the willingness to support indebted collective actors financially (see also Lengfeld et al. 2020).

In this paper, we have chosen these two domains as they are of high salience for the ECE countries. More than other countries, ECE ones profit from already established mechanisms of territorial solidarity within the EU (e.g. due to the European Structural and Investment Funds). ECE countries also took a unique role during the financial crisis. We will discuss the backgrounds in detail in the corresponding sections of the chapter.

\footnotetext{
${ }^{3}$ See Gerhards et al. $(2018,2019 a$, and $2019 b)$ for the discussion and analyses of other domains of solidarity.
} 
3. As our research interest is to determine the extent of a unique European solidarity, we set our focus on a specific spatial level. To determine its strength, a relational comparison with other regional spaces is used. Even though European integration has come a long way and has led to the integration of rights for European citizens (Gerhards and Lengfeld 2015), the nation state has been the central institution of solidarity in many ways and remains so in the present. As national levels of solidarity should be fairly established in most countries, they may serve as a helpful starting point of comparison in the first place. Additionally, since globalisation continuously boosts transnational exchange between people and countries worldwide (Held et al. 2000), we also explore to what extent European solidarity differs from cosmopolitan solidarity at the global level. Hence, we compare the strength of European solidarity for each domain in relation to a similar national and global one.

\section{Methodology}

In the following sections, we present descriptive findings based on the Transnational European Solidarity Survey (TESS). The TESS is a unique survey conducted by the research projects 'SOLIDUS' (EU/Horizon 2020 ) and 'Horizontal Europeanisation' (DFG). Fieldwork was carried out in 2016 in thirteen European countries by the polling institute Kantar TNS Berlin with national subsidies from Kantar TNS, using computer-assisted telephone interviews. ${ }^{4}$ The final sample contains a total of 12,500 respondents, with approximately 1000 respondents per country, including Austria, Cyprus, Germany, Greece, France, Hungary, Ireland, the Netherlands, Poland, Portugal, Slovakia, Spain and Sweden. ${ }^{5}$

To analyse a broad spectrum of countries that allow us to explore the domains of solidarity as deep as possible, the country selection was guided by the following criteria: (1) Did a country receive financial help from an international fund or facility during the Euro crisis? (2) Is the country part of the Eurozone? (3) What kind of regime does the country's welfare state

\footnotetext{
${ }^{4}$ In eleven out of the thirteen countries, the fieldwork was conducted in June and July 2016. In France and Ireland, the fieldwork phase was set for October and November 2016.

${ }^{5}$ For Cyprus, 500 interviews were sufficient due to its scarce population.
} 
belong to (liberal, social democratic, conservative, Mediterranean, postsocialist)? (4) Does the country presently have a rather Eurosceptic or Non-Eurosceptic government? We aimed to sample a diverse set of countries containing a balanced number of states for each criterion. Therefore, we selected Greece, Cyprus, Portugal, Spain and Ireland as receivers of international funds and facilities due to the Euro and banking crisis. Sweden represents a social democratic welfare state regime as the only Scandinavian country in our sample. France, the Netherlands, Germany and Austria are all Western European countries that are part of the Eurozone. Most importantly for this chapter, Poland, Slovakia and Hungary represent East Central European EU member states. By selecting Poland and Hungary, we also covered two non-Eurozone member states.

In order to reap reliable data that is representative of each country's population, we considered two major constraints for the sampling. Firstly, we took the various national landline/mobile phone mix of the gross sample into account.

Secondly, to cover all regions of each country proportional to the number of inhabitants, the numbers in the gross sample were stratified regionally by using NUTS-2 regions. The gross sample was allocated to cells representing the NUTS-2 regions according to their share in the population. Within each cell, the dialed numbers were selected at random. Furthermore, respondents in the survey are citizens eligible to vote in national elections in the respective country exclusively. In landline households with multiple members, the interview partner was identified using the last birthday method.

For our analysis, we solely rely on descriptive analyses of approval rates in general as well as for each country. The approval rates depicted are weighted, either for the whole sample or for each country separately, relying on two different weighting variables. The items used are listed in the Appendix (Tables 1 and 2) with further information on country-specific adaptations as well (Table 3 ).

\section{Fiscal SOLIDARITY}

As a consequence of the 2008 financial crisis that emerged in the US spilling over to European economies, national governments had to stabilise their banks that were threatened by massive loan defaults. Additionally, they experienced an economic depression starting in 2009. Both crises destabilised national budgets especially in the Southern member 
states, leading to the Euro and sovereign debt crisis. In order to bolster the single currency, the EU, its member states and the IMF implemented financial measures towards European fiscal solidarity by granting guarantees and loans to Eurozone countries facing serious financial difficulties, such as Greece, Portugal, Ireland and Cyprus. A permanent, highly capitalised bailout for future crisis situations was established in the form of the temporary European Financial Stability Facility (EFSF), followed by the permanent European Stability Mechanism (ESM). At the same time, the purchased government bonds would support crisis countries. Ultimately, the Eurozone countries made a commitment to reciprocal, albeit limited, European fiscal solidarity in the event of a failure to balance their national budgets.

The main criticism often focused on the problematic legal situation of the financial assistance measures, as they were contradicting the 'No Bailout Clause', which prohibits the liability of the EU as well as member states for debts of other countries (Article 125 TFEU). Within the ECE countries, the assistance measures were additionally regarded as out of proportion. For example, the Slovak Parliament was the first political entity to vote against the expansion of the EFSF in 2011. The opponents of the EFSF argued that it would be unfair for Slovakia, the second poorest country in the Eurozone, to have to secure loans for countries like Greece and Portugal. These countries were not only wealthier than Slovakia, they were also considered to be self-responsible for bringing this emergency upon themselves through lax fiscal policies (Kulish and Castle 2011).

Little is known about attitudes of ECE citizens on European fiscal solidarity from survey research, with most studies focusing on individual-level explanations or face qualifications due to limited numbers of countries. Yet the results are somewhat contradicting. On the one hand, some studies find people from ECE countries to be rather sceptical towards such measures. Slovaks have proven to be among the least supportive in regard to European fiscal solidarity (Kleider and Stoeckel 2018, p. 13; Verhaegen 2018, p. 885), while Poles highly emphasise that states should help themselves in debt situations (Pellegata 2017). However, Juan Díez Medrano et al. (2019) show that Romanians barely differ in their attitudes towards financial assistance measures in comparison with citizens from other member states, such as Denmark. Based on the contradicting results and the briefly outlined political discussion, we expect people from the ECE countries in our study to be more likely to refuse European 
fiscal solidarity than people from the other countries surveyed, especially in comparison with the Southern crisis-stricken ones.

In the TESS survey, we raised the question of whether EU citizens consider the pursued political strategy to be legitimate. Are they willing to show fiscal solidarity with member states faced by heavy economic troubles? To answer this question, we again followed our theoretical concepts' spatial solidarity levels by measuring attitudes towards fiscal solidarity on three spatial levels: between regions within an EU member state, between EU member states and between EU member states and countries outside the EU (see Table 1 in the Appendix for item formulation).

As Fig. 1 shows, two-thirds of all respondents were in agreement with their country providing financial aid to EU countries. Compared to this, fiscal solidarity with countries outside of the EU was significantly lower and not shared by a majority of respondents. These results show that many respondents regarded the EU as an exclusive solidarity space that is distinct from the cosmopolitan idea of universal solidarity. Finally, results demonstrate that the nation state remains the dominant social space for supporting areas in crisis: a huge majority of $83 \%$ of respondents would give financial help to suffering regions within their own country.

How homogeneous are attitudes of citizens from different EU member states towards European fiscal solidarity? As Fig. 2 demonstrates, citizens from each surveyed country agreed on it by majority. Yet, differences exist with an approval rate of $53 \%$ in Hungary and $78 \%$ in Spain. We found the highest approval rates in the former crisis countries of Spain, Ireland and

for a region within own country

for other EU countries for non-EU countries

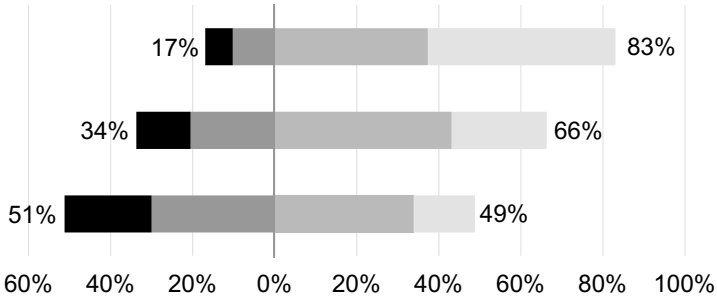

- totally disagree $\square$ tend to disagree $\square$ tend to agree totally agree

Fig. 1 Approval for bailouts in times of crisis by different spatial levels (Source TESS 2016, own calculations, $N=11,927$, relative frequencies, valid answers only, weighted) 


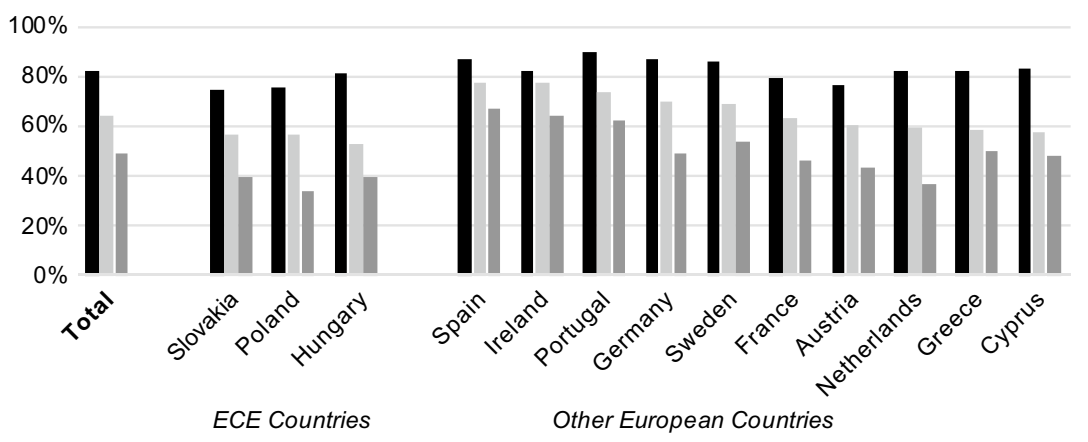

- for a region within own country $\quad$ for other EU countries $\quad$ for non-EU countries

Fig. 2 Approval for bailouts in times of crisis by different spatial levels: country differences (Source TESS 2016, own calculations, $N=11,927$, relative frequencies, valid answers only, weighted)

Portugal. Here, more than $70 \%$ of the population agreed on supporting countries in need. However, only in these countries (and in Sweden), a majority of respondents also wanted their country to provide financial help to countries outside of the EU. This result seems to indicate that citizens experiencing (or having experienced) a severe crisis in their own countries are wary of its negative consequences to a higher extent and thus speak out for supporting other troubled countries. However, this holds true only in countries that overcame the crisis successfully. In Greece and in Cyprus, less than 60\% approved bailouts within the EU.

For the ECE countries of Slovakia, Poland and Hungary, we observe comparable support rates. Despite being below the overall mean, levels of approval are still above the majority threshold of 50\%. Furthermore, with the exception of Hungary (approval rate of 53\%), Slovakia and Poland (both $57 \%$ ) barely differ from other countries with lower approval rates, such as Cyprus (57\%) or Greece (59\%). They therefore do not constitute the extensively sceptical cluster as we had expected.

Besides approval in general, solidarity requires effort and, in the case of the European bailout funds, those providing the assistance must also assume the risk for failing loans. However, this does not specify the form and extent of the aid the individual must provide. If a debtor country were to default on its loan repayments, the donor country would have to stand 
guarantee, and these costs would burden national budgets. As a result, donor countries would have less money available for their own spending, for investments and for servicing their debt. However, it is impossible to say how these constraints would directly impact individual citizens living in the donor countries. This would be different if all EU citizens were to co-finance relief efforts with their own income via a dedicated, direct tax. Thus, a direct European solidarity contribution in the form of an additional tax would result in a heavier direct burden on the population and therefore pose a stress test for the willingness to show European fiscal solidarity.

An additional European tax of this kind does not yet exist but might be plausible in a certain scenario. To test the approval for this, respondents were given a three-part statement with different tax rates and asked to indicate whether they agree or disagree with each of the three proposed rates. All respondents were asked about the same tax rates, but these were combined with different absolute values (in Euro or the national currency) according to the average income of the member states (see Table 3 in the Appendix). With the highest tax rate mentioned first, it was assumed that acceptance of the proposed rates would increase as the tax rates decreased. Hence, if a respondent accepted a certain tax rate, the following question(s) with lower values were skipped (see Table 1 in the Appendix for item formulation).

According to the findings shown in Fig. 3, a clear majority of $61 \%$ of the respondents supported the proposal for an income-related solidarity tax with a minimum contribution to bail out countries within the EU

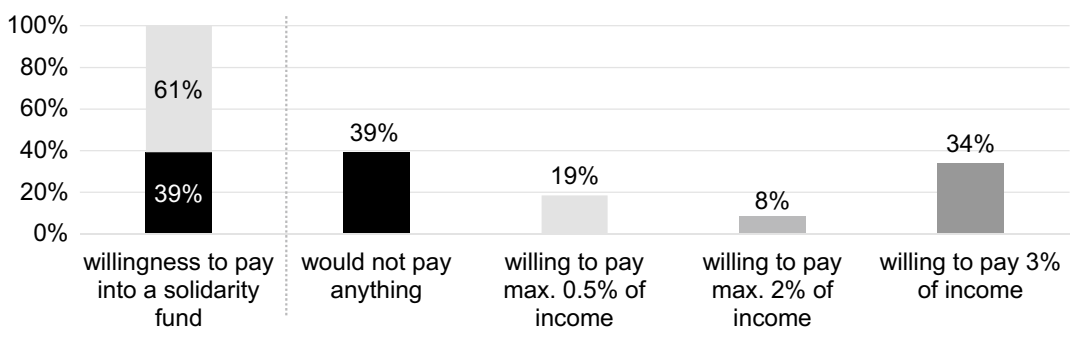

- would not pay anything

willing to pay something

Fig. 3 Willingness to pay into a solidarity fund (Source TESS 2016, own calculations, $N=12,187$, relative frequencies, valid answers only, weighted) 
in budgetary crises, and agreed on one of the three scenarios. Within the group of supporters, 34\% of Europeans would have paid 3\% income tax, followed by $19 \%$ respondents who would not have paid $3 \%$ but $2 \%$, and $8 \%$ of interviewees who only agreed to the $0.5 \%$ tax proposal. These findings indicate that, on average, a hypothetical European solidarity tax would have been accepted by the majority of Europeans living in the countries surveyed.

Figure 4 presents approval and disapproval rates by survey country. The results are even more differentiated between the countries than European fiscal solidarity in general. Even though potential contributors have been in the majority in twelve out of thirteen countries, in France a slight majority of $53 \%$ disagreed on all three proposals. The highest rate of acceptance can be found in Ireland (78\%). Among the six countries with above average acceptance rates are those countries that have received or were receiving bailout funds from the EU and IMF at the time of fieldwork. In these countries, the highest tax rate also received the highest support. Compared to the (former) crisis countries, citizens from Western European countries have been rather sceptical about personally

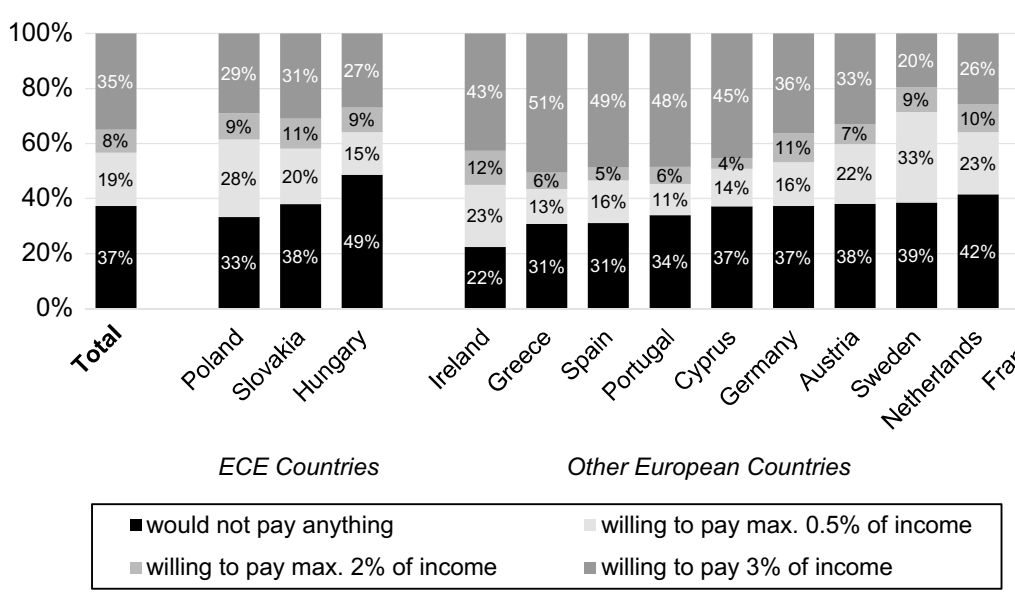

Fig. 4 Willingness to pay into a solidarity fund: country differences (Source TESS 2016, own calculations, $N=12,187$, relative frequencies, valid answers only, weighted) 
contributing to a solidarity tax. Nevertheless, they accepted the general idea by majorities with the exception of France.

Finally, the ECE countries are quite heterogeneous, with half of the Hungarians approving the measures (51\%), while Slovaks (62\%) and Poles (67\%) displayed much higher rates of approval. As the latter two show average rates of acceptance comparable with other member states, e.g. Portugal $(66 \%)$ or Austria (62\%), respondents from France showed an even lower level of approval (47\%) than the Hungarians. This supports the previous results, with the ECE countries not being outstandingly refused on this issue compared to other EU countries, even if Hungary marks an exception to some degree.

To sum up, European bailout funds, such as the ESM, were established by the EU and the IMF to grant loans to Eurozone countries facing the most serious financial difficulties. This deepening of European solidarity was accomplished in a very short time and has also not gone unchallenged in Europe. However, the findings of our analyses point to a great willingness to show European fiscal solidarity, which is much higher than solidarity expressed with troubled countries from outside the EU. This impression is supported by the fact that a good two-thirds of respondents from across the EU would accept a $0.5 \%$ or higher solidarity tax on income. The ECE countries in our sample turned out not to constitute a cluster of refusal, as we had expected. The results from Slovakia and Poland are comparable with those from other member states, while only the Hungarians are somewhat more sceptical. Despite this, they still accept European fiscal solidarity in general, albeit with a slight majority, and are not refusing the possibility of accepting a solidarity tax by a huge majority.

\section{Territorial Solidarity}

With the accession of twelve new member states in 2004 and 2007, the EU faced a huge increase in welfare disparities: in the newly joined ECE countries, the gross domestic product was far below the EU average (Eurostat 2017). Nevertheless, the new member states experienced an increase in economic growth rates in the following years both in absolute and in relative terms (Eurostat 2017). It seemed as if the economic convergence process, one of the central goals of the EU (Article 3 (3) TEU; Article 174 TFEU), was well on its way. With the economic and Euro crises beginning in 2008, the situation changed. Although at a 
slower rate than before, the new member states, especially in the ECE countries, were able to further reduce the gap with the wealthier states, despite lagging considerably behind the richer ones. Despite this, a new cleavage arose with the countries hit hardest by the crisis in Southern Europe falling behind on economic terms (Eurostat 2017).

With the North-South divide reinforcing and the East-West divide basically persisting, spatial disparities seem to be one of the biggest challenges to the EU today. What could be done to reduce inequality between the member states of the EU? One way would be to establish territorial redistribution measures. With the European Structural and Investments Funds, such measures have existed within the EU for several decades already. Yet these measures are limited in two ways: firstly, although they take up a big part of the overall EU budget, they are restricted in their financial scope. Secondly, with the exception of funds like the European Solidarity Fund, established for providing financial help to countries in case of (natural) disasters, such measures aim at enhancing the situation of subnational regions particularly by supporting projects in certain thematic fields.

With the calculation of redistributive measures primarily based on the GDP of regional units, the ECE countries were among the group of member states profiting the most from these measures. With the aim of fostering convergence between EU countries and regions, the funds were used for financial investments in different fields, such as infrastructure (due to the European Regional Development Fund; European Parliament and Council of the European Union 2013a) or to fight poverty (European Social Fund; European Parliament and Council of the European Union 2013b). While the economically weaker member states thus profit from the redistribution system, political debate was rather critical within the wealthier countries. The criticism of the debate on being 'net contributor' states even became one of the central arguments for the successful campaign on leaving the EU in Great Britain (Henley 2016). While there is, to our knowledge, no empirical research analysing citizens' attitudes towards these measures at a European level, we expect that the self-interest of citizens from poorer countries, and their experience as beneficiaries from the already known system, will lead to higher levels of 


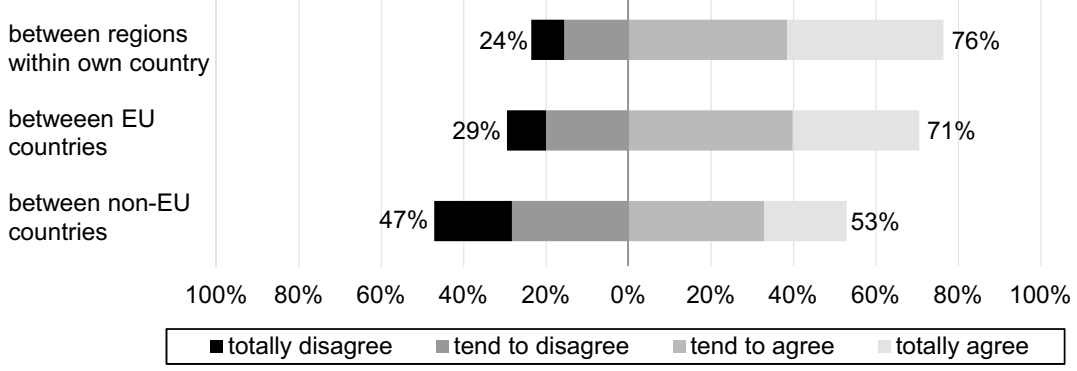

Fig. 5 Approval for reduction of spatial differences by different spatial levels (Source TESS 2016, own calculations, $N=11,843$, relative frequencies, valid answers only, weighted)

approval for a general system of redistribution among EU member states in the ECE countries. ${ }^{6}$

Within the TESS, we surveyed citizens' general attitudes towards the reduction of territorial disparities: Would they support the reduction of wealth differences among different spatial areas? According to our concept of spatial solidarity levels, we measured attitudes towards such a form of solidarity on three different levels: solidarity among regions within one's own nation state, among countries within the EU and among countries worldwide (see Table 2 in the Appendix for item formulation).

Figure 5 shows that a majority of $71 \%$ of the respondents have been in favour of the reduction of spatial differences among EU countries. Support for solidarity between different regions of a nation state was only slightly bigger. For a global reduction of disparities, we find only a scarce majority. Overall, we can observe a huge support for reducing disparities within the EU and the nation state, while a global reduction is controversial.

Do citizens from different countries differ in their acceptance of European territorial solidarity and what do citizens from ECE countries think? Figure 6 shows that in every country under investigation, a majority of respondents have spoken out for the reduction of disparities among the EU states. With a maximum

\footnotetext{
${ }^{6}$ In their study for Spain, Laia Balcells et al. (2015) showed that people from regions that are perceived to be rather wealthier show lower levels of support for measures of regional redistribution. This finding is in line with our expectation.
} 


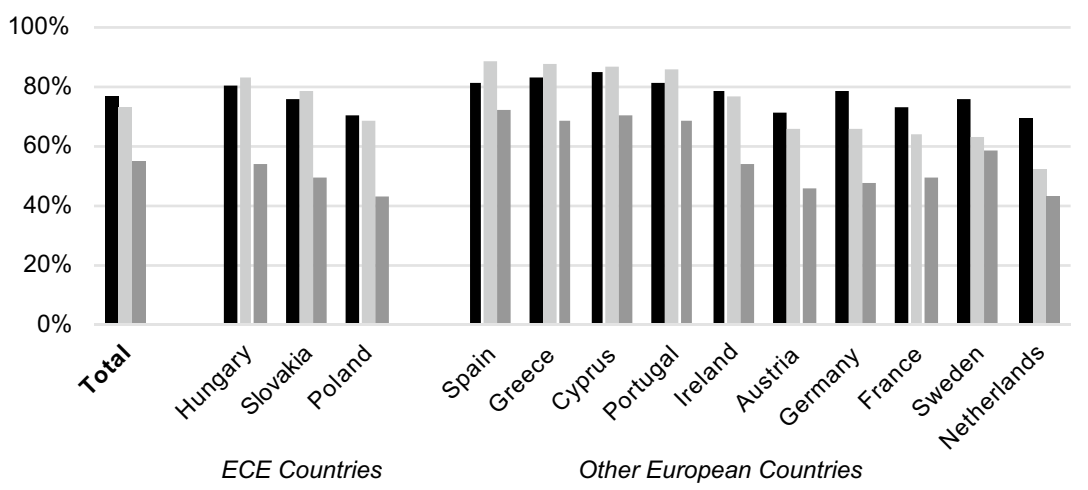

abetween regions within own country $\square$ between EU countries $₫$ between non-EU countries

Fig. 6 Approval for reduction of spatial differences by different spatial levels: country differences (Source TESS 2016, own calculations, $N=11,843$, relative frequencies, valid answers only, weighted)

level of approval of $88 \%$ (Greece) and a minimum of $53 \%$ (the Netherlands), country differences are still very distinct. Once again, regional clusters can be identified; especially among Southern European member states, the idea of reducing disparities within the EU was highly accepted. Although Ireland forms an exception with an acceptance rate above the average (74\%), Western and Northern European countries showed the lowest rates of acceptance in the sample, with the highest level in Austria (66\%) and the lowest in the Netherlands (53\%).

Compared to the mean level of approval, the three ECE countries in the sample showed average approval rates on European territorial solidarity: while approval in Hungary $(83 \%)$ and Slovakia $(78 \%)$ was somewhat above the mean $(74 \%)$, in Poland it was below (68\%). Hence, approval among the ECE countries has been lower than in Southern member states, but higher than in Western and Northern ones. Strikingly, both the Southern and the ECE countries are those countries where the agreement on EU-wide reduction of territorial disparities exceeded the acceptance of the comparable question for reducing differences within the country.

It thus seems that whether a country's citizens are supporting this form of solidarity depends on its economic and financial potential as well as the 
experience as a beneficiary of the current policies. In contrast to populations from Southern and ECE member states, people from Northern and Western European countries may feel disadvantaged by the institutionalisation of comparable measures, as their role as net contributors may be intensified in such a scenario.

However, is there still a majority of citizens supporting measures of reducing spatial disparities in Europe when taking into account that resources are scarce and a (hypothetical) decision has to be made between the three spatial levels? To find out, we asked the respondents to decide on which level the reduction of territorial inequalities should be realised first: within the nation state, among EU countries, or among countries worldwide? Consequently, we asked for a second choice, omitting the option chosen before (see Table 2 in the Appendix for item formulation).

As Fig. 7 shows, the majority of respondents preferred to reduce territorial inequalities within the nation state first. Every fourth has chosen the European level, while $18 \%$ would have liked to reduce disparities among countries worldwide. The priority of one's own nation is not surprising, though the low difference between the relative number of choices of the EU and the global level, on the other hand, is. Regarding the second choice, almost two-thirds of the respondents had chosen the European level, far ahead of their own nation or the global level. Taken together, the pattern is clear: while citizens prioritise reducing disparities within their own nation, the EU is the second most important space of solidarity.

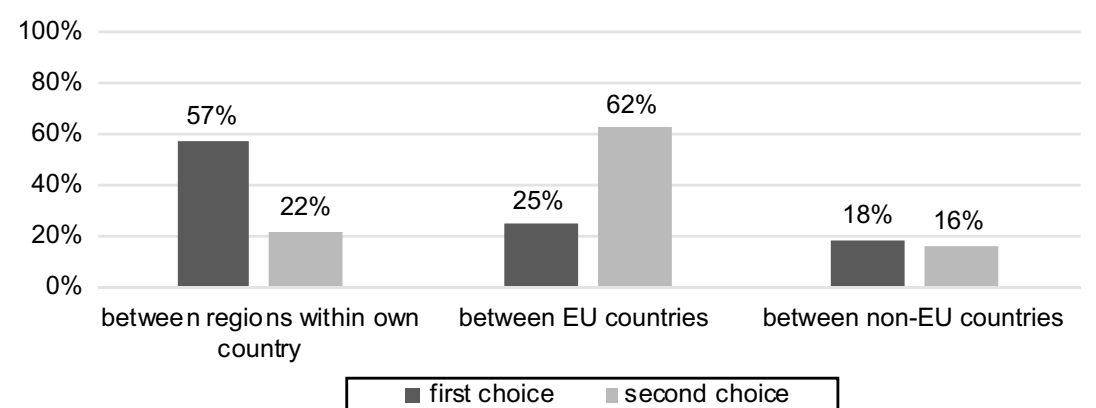

Fig. 7 Where should territorial differences be reduced first and second? (Source TESS 2016, own calculations, $N=11,169$, relative frequencies, valid answers only, weighted) 
Figure 8 depicts country differences. For reasons of simplification, we focus solely on the first choice and on the comparison between national and European solidarity. Unsurprisingly, the EU level is not mentioned as often as the national level in any of the countries. For the European preference, differences are remarkable once again with $17 \%$ selecting the European level in Hungary and $40 \%$ in Greece as the first option. As for the general approval shown before, respondents from Southern European countries preferred EU solidarity to a higher degree than respondents from the Western and Northern countries do. ECE countries do not constitute a homogeneous cluster, with a bigger share mentioning the EU level in Slovakia (35\%) and the lowest among Hungarians (17\%). Consequently, the latter showed a very high level of reducing disparities within their nation state, while the Slovaks did so only on a comparably moderate level. Taken together, the nation state is still the preferred level for reducing territorial disparities in all surveyed countries, being even more pronounced in ECE countries. The significance of the EU varies among EU countries, with the group of ECE countries posing the best example.

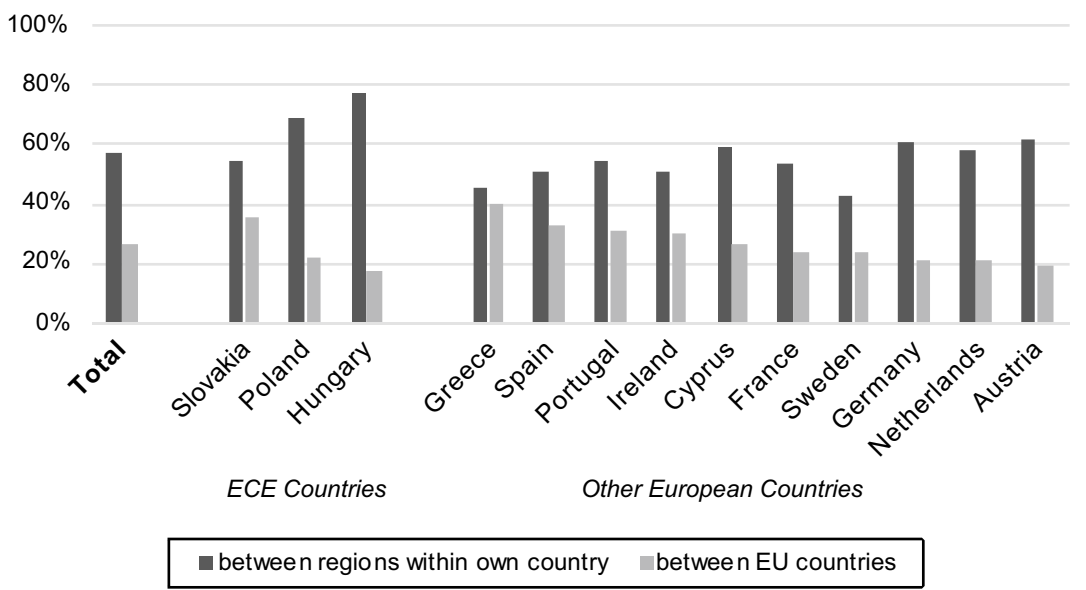

Fig. 8 Where should territorial differences be reduced first? Country differences (Source TESS 2016, own calculations, $N=11,169$, relative frequencies, valid answers only, weighted) 
In sum, our results show that a great majority of EU citizens agreed on reducing disparities among countries within the EU. This majority existed in every country surveyed, even though levels of agreement varied strongly, with the highest levels of approval in Southern countries and lower levels of approval in Northern and Western European ones. Furthermore, the results imply that the nation state is still the most important space for reducing disparities, while the EU comes second before the global level. Although the ECE countries follow the general patterns, they are at the same time rather heterogeneous: while Slovaks showed levels of European territorial solidarity and ranking of the European level to be very close to the European average of our sample, Hungarians and Poles, on the other hand, both emphasised the reduction of the disparities within their countries. Additionally, Hungarians showed comparably higher levels of European territorial solidarity, while in Poland, the approval level was below the average. Citizens from ECE countries do not, therefore, constitute a consistent group of the strongest advocates of European territorial solidarity.

\section{Conclusion}

In this chapter, we asked to what extent citizens of EU countries approved different domains of solidarity. For that, we derived two domains of solidarity for empirical testing, both resulting from EU crises in recent years. Firstly, the Eurozone and sovereign debt crisis-followed by bailout measures introduced by the EU, the ECB as well as the IMF-raised the question whether citizens approve such assistance measures for indebted EU countries. We call this domain European fiscal solidarity. Secondly, as a consequence of the negative economic developments of the crisis countries, as well as the already existing wealth differences among EU member states, the issue of reducing economic disparities by means of redistribution between countries is another politically controversial topic among the EU public. We name this domain European territorial solidaritya kind of solidarity, existing already in the form of the European Social and Investment Funds. After having laid down a systematic approach to grasp and measure solidarity among Europeans, we empirically analysed the question of country differences with a focus on East Central European countries for both domains.

Our descriptive analyses using the 2016 TESS survey revealed a high level of approval for the idea of European fiscal solidarity with two out of 
three respondents agreeing on it. Furthermore, a question on accepting to personally pay into a fictive fund has shown that a clear majority would have also been willing to pay for solidarity with their own income. We expected citizens from ECE countries to show lower levels of support for European fiscal solidarity as they were not affected by the crises themselves and may feel disadvantaged when helping wealthier countries. We found clear country differences, and although Slovakia, Hungary and Poland - the three ECE countries in the TESS - showed among the lowest levels of approval for European fiscal solidarity, we nevertheless found a majority within each. Differences to some other EU member states turned out to be small as well. Furthermore, we found majorities to be willing to personally pay into a fictive fund within each ECE country under observation, although the rates of approval differ with especially Hungarians refusing the idea more often than others. However, among the countries under observation, Hungarians have still been less sceptical than respondents from France.

For European territorial solidarity, we found an even more pronounced level of approval among all respondents than for European fiscal solidarity. Nevertheless, when asked to set out a priority, respondents would have rather chosen to redistribute within the boundaries of their nation state, with the European level being second ahead of a global system of redistribution. With regard to the ECE countries, we expected to find higher approval rates, as they would probably profit from redistributive measures due to their weak economic situation in the EU. Again, country differences in general were remarkable. We found higher approval rates for European territorial solidarity among the ECE countries than in Western and Northern ones, but not exceeding the high rates of approval in the Southern member states. Furthermore, the three countries in focus show diverging levels of approval to some degree. Finally, we identified huge differences among ECE states when it comes to the question of priority, with an average level of preferences for the nationwide equalisation over a European one in Slovakia and the highest rate of national favouritism in Hungary among all countries surveyed.

From this, we derive two important observations. Firstly, despite their relatively young membership within the EU and their comparably weak economic position, citizens from ECE countries do not stand out on matters of solidarity as expected-neither in refusing European fiscal nor in claiming European territorial solidarity. Secondly, differences between the ECE countries under observation are noteworthy. While citizens from 
Slovakia, the only Eurozone country among the three, show the most similar patterns compared to the other EU member states in our sample, Hungary especially stands out with lower rates of approving fiscal solidarity, simultaneously being more demanding in the case of European territorial solidarity with a distinct national focus. In short, to speak of a homogenous group with attitudes contradicting those of other member states would be misleading. We interpret the lack of a controversial cluster in combination with tendencies towards majority approval rates for solidarity among all countries under investigation as a sign of a rather close-knit EU.

As a consequence, further integration steps, like expanding already existing measures of solidarity, such as financial assistance (e.g. the ESM) or redistribution mechanisms (e.g. European Social and Investment Funds), may be legitimated by the citizens of the EU. The peoples of ECE countries do not mark an exception, showing that the idea of a group of veto players in the east is not realistic in these domains.

However, our study faces several limitations, restraining the idea of unconfined expansions and developments of further policies. Firstly, with thirteen countries, the TESS is a very good starting point for a systematic analysis of solidarity in Europe. Nevertheless, the country differences revealed in this study show that we need information for each member state on such issues to be able to rule out the possibility of countries refusing such ideas and becoming veto players in the political arena. Secondly, our sociological perspective is restricted to general ideas. Explicit policies in these fields, such as the introduction of Eurobonds or the expansion of the funding system, may bring along opponents rejecting the practice, not the general idea. Besides research on the effectiveness of different policies, further research on public opinion is needed here. Thirdly, the analyses in this chapter can only make a point on the two domains of solidarity in focus-fiscal and territorial. As we could show elsewhere (Gerhards et al. 2019b), in the case of redistributing refugees or sharing the costs on this matter among EU countries, perspectives on solidarity are highly diverse between the citizens of different EU member states. We therefore recommend caution on what topic which measures of European solidarity are introduced.

\section{APPENDIX}

See Tables 1, 2, and 3 


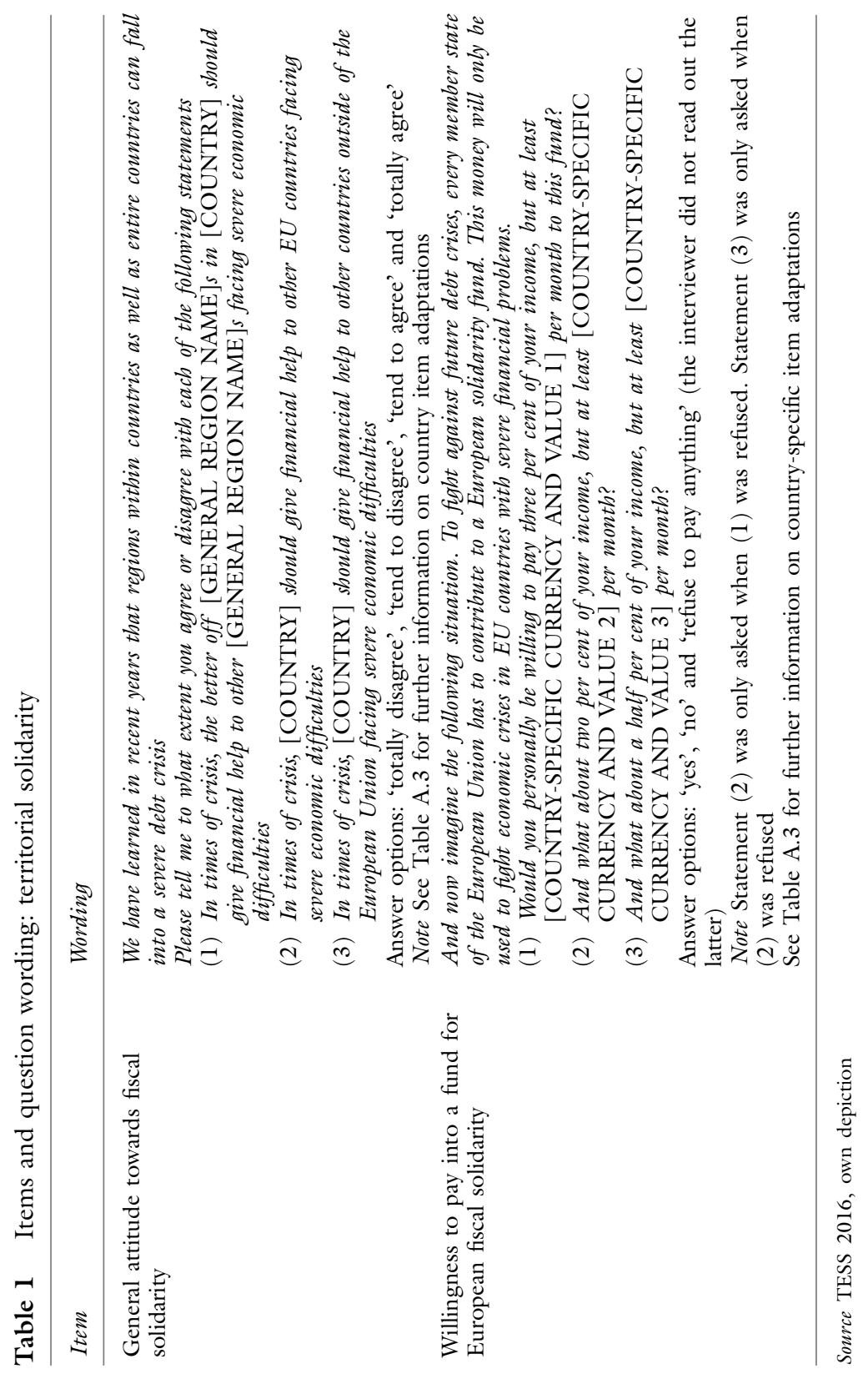




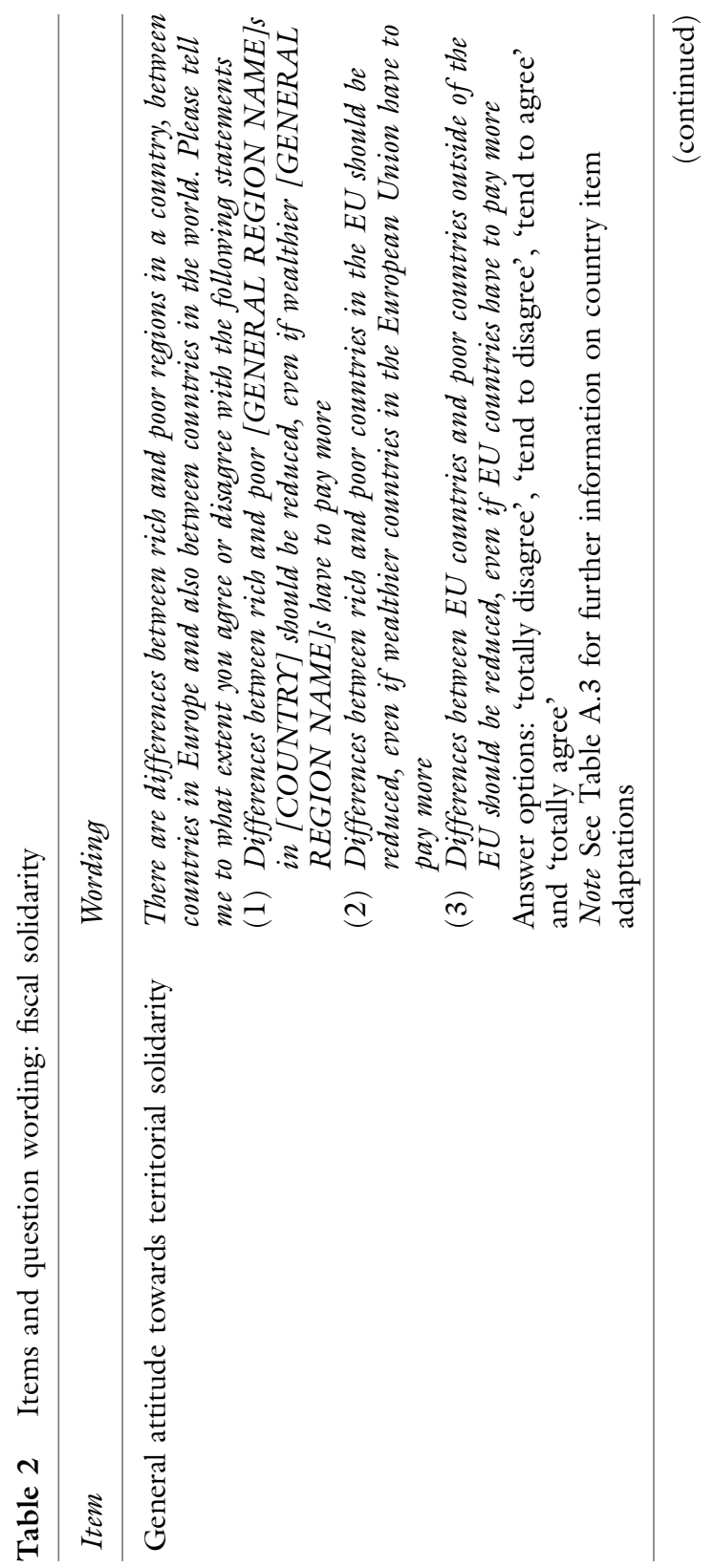




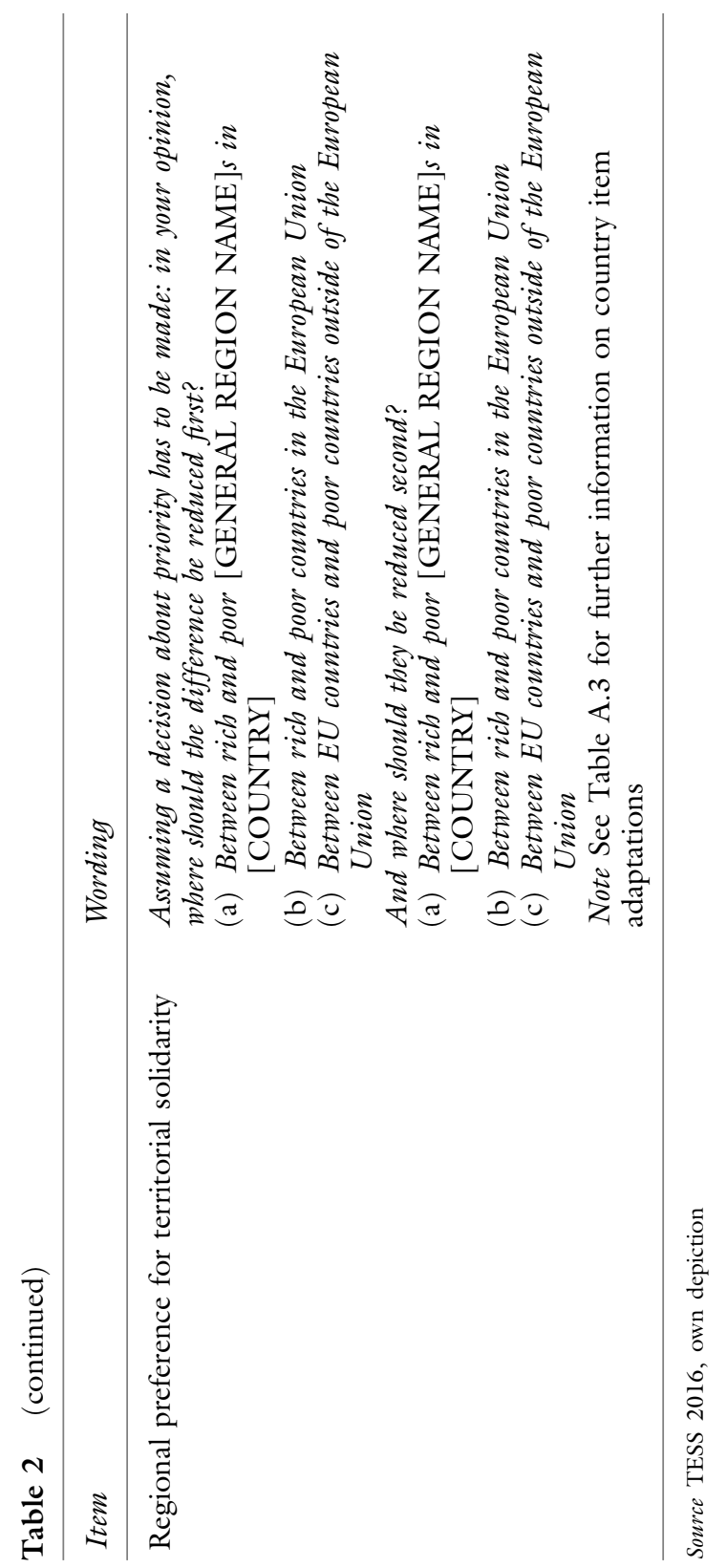




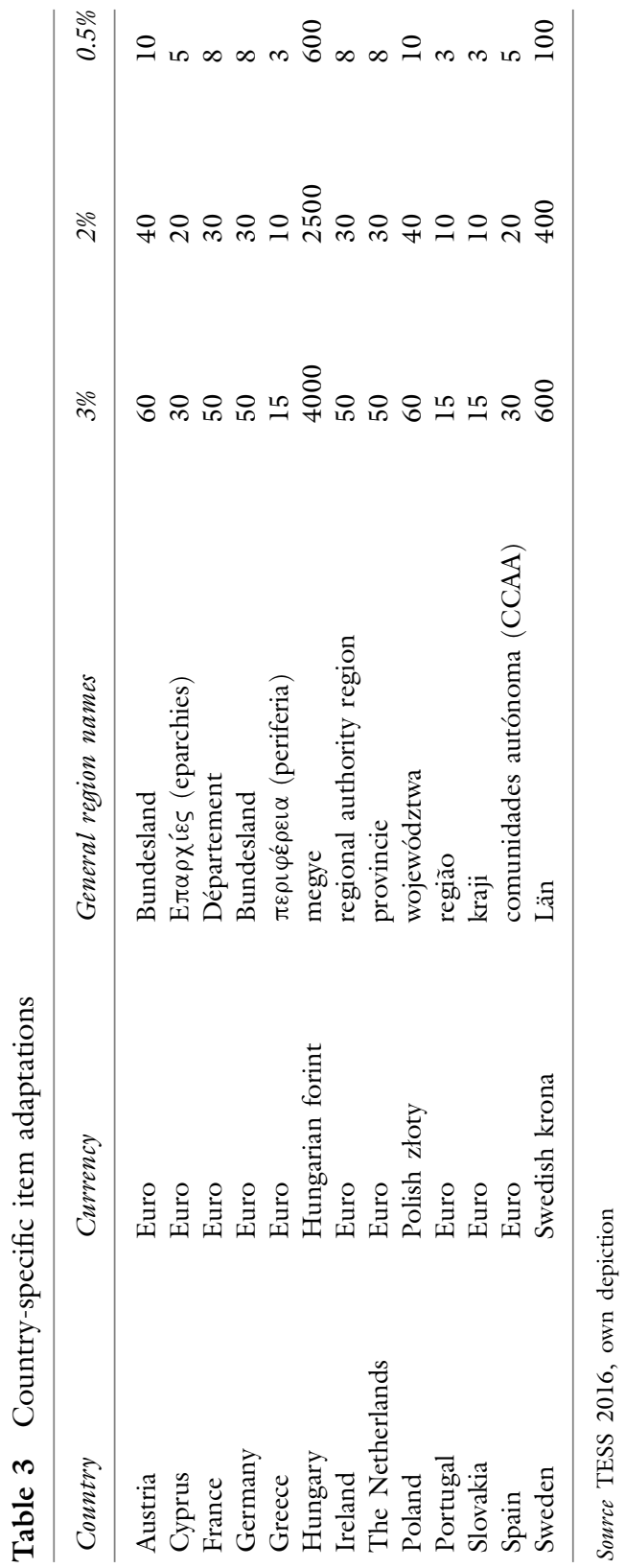




\section{REFERENCES}

Ajzen, Icek. 1991. The Theory of Planned Behavior. Organizational Behavior and Human Decision Processes 50 (2): 179-211.

Balcells, L., J. Fernández-Albertos, and A. Kuo. 2015. Preferences for Interregional Redistribution. Comparative Political Studies 48 (10): 1318-1351.

Bayertz, Kurt. 2000. Die Solidarität und die Schwierigkeiten ihrer Begründung. In Aktuelle Fragen der Rechtsphilosophie, ed. Kurt Seelmann, 85-92. Frankfurt am Main: Peter Lang.

Bayertz, K., and S. Boshammer. 2008. Solidarität. In Handbuch der politischen Philosophie und Sozialphilosophie. Unter Mitarbeit von Robin Celikates und Wulf Kellerwessel, ed. S. Gosepath, W. Hinsch, and B. Rössler, 1197-1201. Berlin: De Gruyter.

Díez Medrano, J., I. Ciornei, and F. Apaydin. 2019. Explaining Supranational Solidarity. In Everyday Europe: Social Transnationalism in an Unsettled Continent, ed. E. Recchi, A. Favell, F. Apaydin, R. Barbulescu, M. Braun, I. Ciornei, N. Cunningham, J. Díez Medrano, D. Duru, L. Hanquinet, J. S. Jensen, S. Pötzschke, D. Reimer, J. Salamonska, M. Savage, and A. Varela, 137-170. Bristol: Policy Press.

European Parliament and Council of the European Union. 2013a. Regulation $1301 / 2013$ on the European Regional Development Fund and on Specific Provisions Concerning the Investment for Growth and Jobs. Official Journal of the European Union L 347: 289-302.

European Parliament and Council of the European Union. 2013b. Regulation 1304/2013 on the European Social Fund. Official Journal of the European Union L 347: 470-486.

Eurostat. 2017. GDP per capita in PPS (tec00114). Eurostat-Tables, Graphs and Maps Interface (TGM). http://ec.europa.eu/eurostat/tgm/table.do?tab= table\&init $=1$ \&language $=$ en\&pcode $=$ tec 00114 \&plugin $=1$. Accessed 23 March 2017.

Gelissen, John. 2000. Popular Support for Institutionalised Solidarity. A Comparison Between European Welfare States. International Journal of Social Welfare 9 (4): 285-300.

Gerhards, Jürgen, and H. Lengfeld. 2015. European Citizenship and Social Integration in the European Union. London and New York: Routledge.

Gerhards, J., H. Lengfeld, M. Soler, Z.S. Ignácz, F.K. Kley, M. Priem, R. Ramos, and J. Suriñach. 2017. How Strong Is European Solidarity? Results from the Transnational European Solidarity Survey (TESS). Report (unpublished).

Gerhards, J., H. Lengfeld, Z.S. Ignácz, F.K. Kley, and M. Priem. 2018. How Strong Is European Solidarity? Preliminary Results from a Survey Conducted in 13 Member States of the EU. Arbeitsbericht des Instituts für Soziologie 75.

Gerhards, J., Z.S. Ignácz, F.K. Kley, H. Lengfeld, and M. Priem. 2019a. How Strong Is European Welfare Solidarity? Results from a Comparative Survey 
Conducted in 13 EU Member States. In Horizontal Europeanisation. The Transnationalisation of Daily Life and Social Fields in Europe, ed. Martin Heidenreich, 39-62. Abingdon and New York: Routledge.

Gerhards, J., H. Lengfeld, Z.S. Ignácz, F.K. Kley, and M. Priem. 2019b. European Solidarity in Times of Crisis. Insights from a Thirteen-Country Survey. Abingdon and New York: Routledge.

Hechter, Michael. 2001. Sociology of Solidarity. In International Encyclopedia of the Social of Behavioral Sciences, ed. N.J. Smelser and P.B. Baltes, 1458814591. Amsterdam: Elsevier.

Held, D., A.G. McGrew, D. Goldblatt, and J. Perraton. 2000. Global Transformations: Politics, Economics and Culture. In Politics at the Edge, ed. C. Pierson and S. Tormey, 14-28. Political Studies Association Yearbook Series. London: Palgrave Macmillan.

Henley, Jon. 2016. Why Vote Leave's $£ 350 \mathrm{~m}$ Weekly EU Cost Claim Is Wrong. The Guardian. https://www.theguardian.com/politics/realitycheck $/ 2016 / \mathrm{may} / 23 /$ does-the-eu-really-cost-the-uk-350m-a-week. Accessed 31 March 2020.

Kleider, H., and F. Stoeckel. 2018. The Politics of International Redistribution: Explaining Public Support for Fiscal Transfers in the EU. European Journal of Political Research 58 (1): 4-29.

Kulish, N., and S. Castle. 2011. Slovakia Rejects Euro Bailout. The New York Times. http://www.nytimes.com/2011/10/12/world/europe/slovakleader-vows-to-resign-if-bailout-vote-fails.html. Accessed July 192017.

Lengfeld, H., F.K. Kley, and J. Häuberer. 2020. Contemplating the Eurozone Crisis: Are European Citizens Willing to Pay for a European Solidarity Tax? Evidence from Germany and Portugal. European Societies 22 (3): 337-367.

Pellegata, Alessandro. 2017. Citizens' Views on inter-state Solidarity and Social Europe. EuVisions. http://www.euvisions.eu/citizens-views-on-inter-statesolidarity-and-social-europe/. Accessed 31 March 2020.

Verhaegen, Soetkin. 2018. What to Expect from European Identity? Explaining Support for Solidarity in Times of Crisis. Comparative European Politics 16: 871-904. 
Open Access This chapter is licensed under the terms of the Creative Commons Attribution 4.0 International License (http://creativecommons.org/licenses/ by $/ 4.0 /$ ), which permits use, sharing, adaptation, distribution and reproduction in any medium or format, as long as you give appropriate credit to the original author(s) and the source, provide a link to the Creative Commons license and indicate if changes were made.

The images or other third party material in this chapter are included in the chapter's Creative Commons license, unless indicated otherwise in a credit line to the material. If material is not included in the chapter's Creative Commons license and your intended use is not permitted by statutory regulation or exceeds the permitted use, you will need to obtain permission directly from the copyright holder.

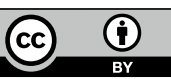

